НАУКОВИЙ ВІСНИК

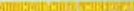

tanimail

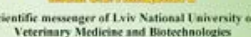

7

9uw wosk

iो iा

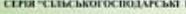
Toм 21 Nig 90

2019
Науковий вісник Аьвівського національного університету ветеринарної медицини та біотехнологій імені С.3. Гжицького. Серія: Сільськогосподарські науки

\author{
Scientific Messenger of Lviv National University
} of Veterinary Medicine and Biotechnologies.

Series: Agricultural sciences

UDC 639.31 .043

\title{
Morphometric estimation of Rainbow Trout for feeding Aller Aqua and Aquafeed Fischfutter
}

\author{
I.Y. Bobel, J.I. Pivtorak
}

Stepan Gzhytskyi National University of Veterinary Medicine and Biotechnologies Lviv, Ukraine

Article info

Received 22.01.2019

Received in revised form 25.02.2019

Accepted 26.02.2019

Stepan Gzhytskyi National University of Veterinary Medicine and Biotechnologies Lviv,

Pekarska Str., 50, Lviv,

79010, Ukraine.

Tel.: +38-093-469-60-44

E-mail:Irynabobel@gmail.com
Bobel, I.Y., \& Pivtorak, J.I. (2019). Morphometric estimation of Rainbow Trout for feeding Aller Aqua and Aquafeed Fischfutter. Scientific Messenger of Lviv National University of Veterinary Medicine and Biotechnologies. Series: Agricultural sciences, 21(90), 21-25. doi: 10.32718/nvlveta9004

Scientific research was based on certain morphometric indices of various trout groups, which allows us to draw conclusions about the effectiveness of fish feeding with Aller Aqua and Aquafeed Fischfutter. The main task of trout farming is to obtain a commodity trout for the shortest possible time. In this case, the intensity of the growth of rainbow trout leads to the absence of feed, which is used in its cultivation. For active growth and development of fish, a high level of protein in the stern is required, which should be used specifically for plastic exchange, and not for the energy organism. Inner-shell left arms inviting them to optimize their chemical composition of feed, but they are energetic, perform in the body of fish a number of other vital functions: structure, regulatory and others, and serve as precursors of many biologically active substances that have validity and hormones. While growing rainbow trout, it is necessary to take into account its phenotypes of characteristics, which show that the level of breeding stability of the fish population and determines the attractiveness of products on the consumer market. The composition of feed primarily affects the metabolism of fish, which determines the intensity of their growth and development, and is also realized by trout. Fodder for the cultivation of salmon fish are made from industrial fishing waste. An economically viable alternative source of raw materials serves vegetal products (oils, sunflower proteins, soybeans, maize glutenin, and others), which, however, do not have a forage base of predatory fish appearing in natural waters. At present, the influence of different compositions on the morphometric and physiological biochemical characteristics of the culture, especially salmon, is actively studied, but these problems remain unchanged. The dynamics of the intensity of growth and development of rainbow trout is ensured by the feeding regime of fish. The publication of the published differences in the nature of the massif and the flow of rainbow trout species, which ensure the use of Aller Aqua and Aquafeed Fischfutter mixed fodders.

Key words: rainbow trout, Aller Aqua feed, Aquafeed Fishsfutter, fish industry, trout feed, metabolic processes, diet, growth rate, fishery research, fish production, feed rate, feed costs, energy value, feed nutrition.

\section{Морфометрична оцінка райдужної форелі за згодовування кормів Aller Aqua тa Aquafeed Fischfutter}

\author{
І.Ю. Бобель, Я.І. Півторак
}

Львівський національний університет ветеринарної медицини та біотехнологій імені С.3. Гжицького м. Львів, Украӥна

Наукові дослідження, щуо полягали у визначенні морфометричних показників різновікових груп форелі, дозволяють нам зробити висновки щодо ефективності годівлі риб кормами фірми Aller Aquа та Aquafeed Fischfutter. Основне завдання форелевих господарств полягає в отриманні товарної форелі за максимально короткий термін. При иьому інтенсивність росту райдужної форелі головним чином залежить від складу кормів, які використовуються при ї̈ вирошуванні. Для активного росту і розвитку риб необхідний високий рівень білка в кормі, шо повинен використовуватися саме для пластичного обміну, а не для енерговитрат організ- 
му. Вміст в кормах ліпідів дозволяє оптимізувати їх хімічний склад, оскільки вони, окрім енергетичної виконують в організмі риб ряд інших життєво важливих функцій: структуроутворюючу, регуляторну та інші, а також служать попередниками багатьох біологічно активних речовин, в тому числі і гормонів. Під час вирошування райдужної форелі необхідно враховувати ї̈ фенотипові характеристики, щу відображають рівень селекційної стабільності популячій риби і визначають привабливість продукиї на споживчому ринку. Склад кормів насамперед впливає на метаболізм риб, який визначає інтенсивність їхнього росту і розвитку, а також якість реалізованої форелеводами продукиї. Комбікорми для вирощування лососевих риб виробляють переважно з відходів промислового рибальства. Економічно обтрунтованим альтернативним джерелом сировини служать продукти рослинного походження (олї, протеїн соняшнику, сої, глютелін кукурудзи та інші), які, однак, не відповідають кормовій базі хижих риб, щзо перебувають у природних водоймах. В даний час активно вивчається вплив різних складів комбікормів на морфометричні та фізіологобіохімічні характеристики культивованих риб, особливо лососевих, проте ці питання все ще залишаються маловивченими. Динаміка іінтенсивності росту і розвитку райдужної форелі залежить від режиму годівлі риб. У иій публікації наведено відмінності у прирості живої маси та темпах росту райдужної форелі, які обумовлені використанням комбікормів Аllег Аqиа та Аqиағееd Fischfutter.

Ключові слова: райдужна форель, корм Aller Aqua, Aquafeed Fishsfutter, рибна галузь, комбікорм для форелі, обмінні процеси, раціон, інтенсивність росту, рибогосподарські дослідження, рибопродукція, кормовий коефіцієнт, витрати корму, енергетична цінність, поживність кормів.

\section{Вступ}

Вирощування форелі в умовах замкнутого водопостачання пов'язане із такими господарськими проблемами, як наявність природніх джерел артезіанського походження, які можна спрямувати в загальне басейнове русло із урахуванням щільності посадки на одиницю площі, яка зазвичай є високою. Наступною проблемою є годівля - починаючи від личинки, малька та дорослої риби (FAO, 2009; Ruyter et al., 2010; Collins et al., 2012; Bozhyk \& Bachuk, 2014).

Годівельний фактор - це організація виробничого процесу, спрямована на забезпечення життєвих потреб риби у поживних, мінеральних і біологічно активних речовинах для одержання запланованого виробництва рибопродукції високої якості (Gümüş \& İkiz, 2009; Yun et al., 2011; Pivtorak \& Bobel, 2017).

Традиційно в практиці годівлі форелі у обмежених за площею басейнах використовують штучно виготовлені комбікорми, які за поживністю відрізняються між собою та мають різну вартість. При цьому корми, як і кожна складова система годівлі риби, повинні розглядатися як важливий економічний фактор виробництва, оскільки у структурі собівартості отриманої продукції частка кормів на ії одержання займає 75$80 \%$ і більше (Sherman et al., 2002; Thanuthong et al., 2011).

Годівлю форелі варто здійснювати за чітким графіком, оскільки у неї виробляються умовні рефлекси, завдяки яким корм споживається ефективніше та за коротший відрізок часу. Кількість корму розраховують за нормами, вираженими у відсотках до маси тіла риби. Добовий раціон однаковими частинами розподіляють на число годівель упродовж світлового дня, яке визначають залежно від температури води та фізіологічного стану риби. В період вирощування личинок у лотках iї годують через кожні 1,5-2 год, у разі вирощування товарної риби - через 2-4 год (Mitrofanov, 1977).

Повноцінність нормованої годівлі можна визначити за рибницькими критеріями, які грунтуються на продуктивній дії кормів у процесі вирощування рибопосадкового матеріалу: це приріст маси риби, рибопродуктивність, якість продукції, витрати кормів на одиницю рибопродукції, кількість і якість статевих продуктів, стан здоров’я.
Таким чином, у вказаному вище короткому вступі, який сформовано на основі літературних джерел, прослідковується необхідність подальших досліджень, спрямованих на вивчення впливу гранульованих комбікормів різної поживної цінності на функціональний стан росту і розвитку риб.

В основу наших досліджень покладено завдання оптимізації процесу годівлі форелі за використання кормів фірмових виробників “Aller Aqua" та “Aquafeed Fishsfutter" 3 подальшою оцінкою їхньої ефективності, що підкреслює актуальність таких досліджень.

Мета $i$ завдання досліджень полягають у з'ясуванні впливу кормів Aller Aqua i Aquafeed Fishsfutter на морфометричні параметри різновікової форелі, вирощуваної у господарстві ПП “Західна рибна компанія".

\section{Матеріал і методи досліджень}

Матеріалом досліджень слугували цьоголітки та товарна форель, що вирощувались в дослідних басейнах приватного підприємства "Західна рибна компанія" та складали окрему контрольну групу, в період 2017-2018 рр., а також дві дослідні групи форелі, що утримувалась в окремих басейнах та годувались кормами різних виробників. Басейни господарства знаходяться у с. Тучне Перемишлянського р-ну Львівської області. Вирощувальні басейни мають площу $48 \mathrm{~m}^{2}$, устатковані системою постійної подачі води та кисню, водовідведення, а також аераторами та терморегуляторами. Водопостачання здійснюється із артезіанських джерел, що знаходяться на території господарства, вода 3 яких надходить у водовідстійник, 3 якого подається мережею труб у басейни.

Об'єктом досліджень була форель цьоголітки, товарної, тричі на місяць проводили контрольні облови, під час яких проводили проміри райдужної форелі, відібравши із кожного басейну середню пробу.

Під час досліджень проводили визначення основних лінійних показників з використанням методик, загальноприйнятих у рибництві. Морфометричну оцінку проводили шляхом вимірювання та зважування риби (Lakin, 1990; Kucheruk et al., 2007). Діапазон коливань коефіцієнтів варіації всіх морфометричних 
ознак у райдужної форелі, вирощеної в басейнах, свідчить про певну мінливість цих ознак.

Були визначені такі параметри, як повна довжина риби - ab , довжина тулуба-od , довжина голови - aо, довжина рила - an, найбільша висота тіла - qh, найменша висота тіла - ik, обхват - u, маса риби - m (рис. 1).

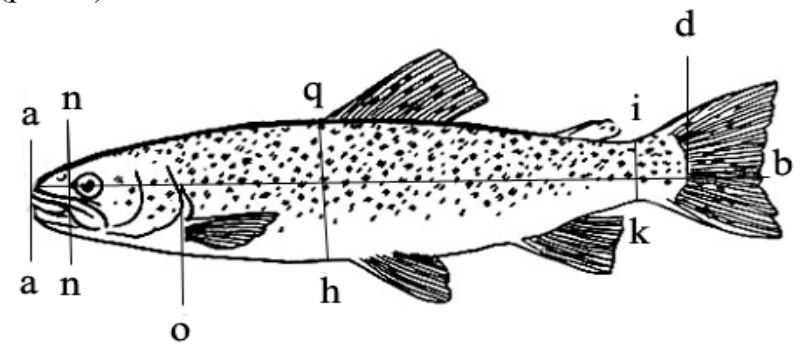

Рис. 1. Лінійні параметри форелі

Лінійні параметри форелі визначали за допомогою вимірювання різних структур тіла форелі на міліметровочному папері і циркулем, 3 точністю до 0,1 мм, масу визначали на електронних вагах 3 точністю до 1 мг.

Статистична оцінка проведена із розрахунком середнього показника $(\mathrm{X})$, стандартного відхилення $(\sigma)$, середньої помилки $(\mathrm{mX})$, коефіцієнта варіації $(\mathrm{CV})$, достовірність різних середніх значень оцінювали за критерію Стьюдента. Статистичну обробку морфометричних показників проводили в Microsoft Office Excel. Коефіцієнт вгодованості, який характеризує якість вирощеної риби, розраховували відповідно до формули Т. Фультона:

$$
\mathrm{K}_{\mathrm{y}(\phi)}=\mathrm{m} \times 100 / \mathrm{l}^{3}
$$

де $\mathrm{K}_{\mathrm{y}(\phi)}$ - коефіцієнт вгодованості; $\mathrm{m}$ - маса риби, г; 1 - довжина риби, см (ab).

\section{Результати та їх обговорення}

Рибництво відіграє важливу роль у забезпеченні населення найбільш повноцінними дієтичними продуктами харчування, тому годівля риби має особливе значення при їі вирощуванні, оскільки рибопродуктивність штучних водойм може бути підвищена в десятки разів.

Відомо, що інтенсивність росту форелі та ефективність рибопродуктивності залежить від складу іiі раціону, який в умовах басейнового вирощування визначається якістю штучно виготовлених кормів.

За типом живлення риб поділяють на три основні групи: рослиноїдні (фітофаги), твариноїдні (зоофаги) i всеїдні (фітофаги). Процес травлення поділяється на дві фази: ефективну - за якої гідролізуються у травному каналі легкоперетравні речовини корму, і залишкову - за якої розщеплюються важкоперетравні. За першої фази перетравлюється до 80\% маси корму i вона триває у хижих риб близько трьох діб. Залишкове травлення триває півтори доби.

Потреба форелі в енергії, поживних і біологічноактивних речовинах залежить від віку, маси тіла та вгодованості. До основних поживних речовин, необхідних для нормального розвитку, реалізації продуктивних та репродуктивних якостей належать: протеїн (з незамінними амінокислотами), жир (з незамінними жирними кислотами), вуглеводи, мінеральні елементи та вітаміни.

Саме для реалізації поставленого перед нами завдання було необхідно дати оцінку ефективності використання в годівлі райдужної форелі двох гранульованих кормосумішей Aller Aqua та Aquafeed Fishsfutter в умовах конкретного господарства Західного регіону України.

На товарне вирощування форель була посаджена у басейни площею $42 \mathrm{~m}^{2}$ та глибиною 1,3 м, при їх заповненні водою - 1 м, окрім цього було сформовано ще два дослідні басейни, менші за об'ємом - 2 м $^{3}$ та заповнені водою на $1,65 \mathrm{~m}^{3}$.

Добова потреба сухих гранульованих сумішей для вирощування цьоголіток і товарної форелі розраховувалася залежно від температури води, маси риби та розміру гранул (Pivtorak \& Bobel, 2017).

\section{Таблиця 1}

Морфометричні показники цьоголіток райдужної форелі $(\mathrm{M} \pm \mathrm{m}, \mathrm{n}=10)$

\begin{tabular}{lrrr}
\hline \multicolumn{1}{c}{ Показники } & \multicolumn{1}{c}{ Контрольний } & Досейни & 3 \\
\cline { 2 - 4 } & 1 & $28,3 \pm 0,56^{*}$ & $27,3 \pm 0,44$ \\
Маса риби, г & $25,3 \pm 0,48$ & $13,43 \pm 0,51$ & $13,3 \pm 0,47$ \\
Довжина, см & $13,04 \pm 0,50$ & $9,1 \pm 0,39$ & $8,91 \pm 0,41$ \\
- довжина тулуба, см & $8,84 \pm 0,40$ & $0,69 \pm 0,04$ & $0,66 \pm 0,04$ \\
- довжина рила, см & $0,67 \pm 0,05$ & $2,33 \pm 0,08$ & $2,38 \pm 0,06$ \\
- довжина голови, см & $2,26 \pm 0,07$ & $4,22 \pm 0,5$ & $4,18 \pm 0,03$ \\
Найбільша висота тіла, см & $4,1 \pm 0,04$ & $1,96 \pm 0,01$ & $1,73 \pm 0,01$ \\
Найменша висота тіла, см & $1,69 \pm 0,01$ & $8,73 \pm 1,03$ & $1,65 \pm 0,93$ \\
Обхват тіла, см & $8,47 \pm 0,98$ & $1,17 \pm 0,07$ & 65,1 \\
Коефіцієнт вгодованості & $1,14 \pm 0,06$ & 65 & \\
Індекс обхвату,\% & 64,95 & &
\end{tabular}

Примітка: *P <0,05, **P $<0,01, * * * \mathrm{P}<0,001$

Спостереження за функціональним станом риби у дослідних басейнах проводилися щоденно 3 визначенням в кінці кожного місяця морфометричних по- казників. Середні дані цих промірів наведені у таблицях 1 і 2. Слід наголосити, що за весь період досліджень форель споживала практично одинакову кіль- 
кість кормів. Однак, використання у годівлі риби досліджуваних видів кормів по різному позначилося на низці морфометричних показників як цьоголіток, так і товарної райдужної форелі.

Зокрема, проведений протягом всього дослідного періоду аналіз функціонального стану розвитку і росту райдужної форелі показав кращі показники у дослідних басейнах і особливо № 2, риба якого споживала гранульовану кормову суміш виробництва фірми Aller Aqua. Так, відмічено вірогідне збільшення маси риби як у цьоголіток, так і товарної риби. Риба із цього басейну відрізняється високою активністю та низьким відходом. За окремими морфометричними показниками, такими як довжина тулуба, рила, голови, також спостерігаються відмінності порівняно з рибами контрольного басейну. Аналогічні відмінності відмічено й за висотою і обхватом тіла, що вказує на більш інтенсивні процеси засвоєння поживних речовин даного корму.

Таблиця 2

Морфометричні показники товарної райдужної форелі $(\mathrm{M} \pm \mathrm{m}, \mathrm{n}=10)$

\begin{tabular}{|c|c|c|c|}
\hline \multirow{3}{*}{ Показники } & \multicolumn{3}{|c|}{ Басейни } \\
\hline & \multirow{2}{*}{$\begin{array}{c}\text { Контрольний } \\
1 \\
\end{array}$} & \multicolumn{2}{|c|}{ Дослідні } \\
\hline & & 2 & 3 \\
\hline Маса риби, г & $324,9 \pm 16,6$ & $355,6 \pm 17,08 * *$ & $337,7 \pm 16,7$ \\
\hline Довжина, см & $28,0 \pm 0,51$ & $28,6 \pm 0,48$ & $28,3 \pm 0,50$ \\
\hline - довжина тулуба, см & $18,6 \pm 0,25$ & $19,2 \pm 0,24$ & $18,9 \pm 0,23$ \\
\hline - довжина рила, см & $1,75 \pm 0,06$ & $1,8 \pm 0,06$ & $1,7 \pm 0,05$ \\
\hline - довжина голови, см & $5,83 \pm 0,37$ & $6,0 \pm 0,35$ & $5,9 \pm 0,39$ \\
\hline Найбільша висота тіла, см & $8,34 \pm 0,97$ & $8,58 \pm 0,60$ & $8,49 \pm 0,89$ \\
\hline Найменша висота тіла, см & $2,92 \pm 0,22$ & $3,0 \pm 0,21$ & $2,97 \pm 0,21$ \\
\hline Обхват тіла, см & $18,01 \pm 1,43$ & $18,6 \pm 1,35$ & $18,4 \pm 1,42$ \\
\hline Коефіцієнт вгодованості & $1,48 \pm 1,11$ & $1,52 \pm 1,09$ & $1,49 \pm 1,10$ \\
\hline Індекс обхвату,\% & 64,3 & 65 & 65 \\
\hline
\end{tabular}

Примітка: *P $<0,05, * * \mathrm{P}<0,01, * * * \mathrm{P}<0,001$

Важливо при цьому підкреслити те, що позитивні відмінності у морфометричних показниках райдужної форелі другого дослідного басейну мали найвищий коефіціент вгодованості. Риба цього басейну мала високу товарну цінність під час реалізації.

Таким чином, проаналізувавши компонентні складники досліджуваних гранульованих кормових сумішей, можемо сказати, що за поживністю вони дуже схожі, проте у кормах Aller Aqua на відміну від Aquafeed Fishsfutter міститься крилеве і кров'яне борошно та соняшниковий протеїн, що поліпшує їхню поживність і тим самим забезпечує вищу кормову цінність та ефективність.

Динаміка приросту довжини і маси райдужної форелі залежить від режиму годівлі риби. Показані відмінності в прирості маси і темпах росту за досліджуваний період, які обумовлені, ймовірно, складом комбікормів. Можемо сказати, що рівень засвоюваності кормів близький до $2 \%$. Якість кормів визначає темп приросту довжини і маси риб, інтенсивність яких залежить від вмісту білка, структурних ліпідів і $\omega 3$ поліненасичених жирних кислот в комбікормах.

\section{Висновки}

Проведені дослідження за порівняльною оцінкою продуктивної дії гранульованих кормових сумішей Aller Aqua i Aquafeed Fishsfutter на параметри росту i розвитку райдужної форелі дають підставу стверджувати про доцільність використання кормів Aller Aqua в годівлі риб.

Перспективи подальших досліджень. Будуть спрямовані на вивчення впливу гранульованих кормів Aller Aqua на гематологічні показники, якісні показ- ники рибної продукції, іiї харчову цінність та визначення економічної ефективності при годівлі форелі.

\section{References}

Bozhyk, V.Y., \& Bachuk, Y.O. (2014). Suchasnyi stan i perspektyvy rozvytku foelivnytstva $\mathrm{V}$ zakhidnomu rehioni Ukrainy. Naukovyi visnyk LNUVMBT im. Hzhytskoho, 3(60), 26-31 (in Ukrainian).

Collins, S.A., Desai, A.R., Mansfield, G.S. et al. (2012). The effect of increasing inclusion rates of soybean, pea and canola meals and their protein concentrates on the growth of rainbow trout: Concepts in diet formulation and experimental design for ingredient evaluation. Aquaculture, 344-349, 90-99. doi: $10.1016 /$ j.aquaculture.2012.02.018.

FAO The state of world fisheries and aquaculture, 2008. (2009). FAO Fisheries and Aquaculture Department. Food and Agriculture Organization of the United Nations, 96. www.fao.org.

Gümüş, E., \& İkiz, R. (2009). Effect of dietary levels of lipid and carbohydrate on growth performance, chemical contents and digestibility in rainbow trout, Oncorhynchus mykiss Walbaum. Pakistan Vet. J., 29(2), 59-63. http://pvj.com.pk/pdf-files/29_2/59-63.pdf.

Kucheruk, A.I., Mruk, A.I., \& Galoyan, L.L. (2017) Morfometrychna harakterystyka remontnomatochnoho stada strumkovoyi foreli (SALMOTRUTTA. FARIOL), vyroshhenoyi v umovax industrialnogo gospodarstva «Ishxan», Visnyk Poltavs`koyi derzhavnoyi agrarnoyi akademiyi, 3(41), 65-75. doi: 10.15407/fsu2017.03.065 (in Ukrainian).

Lakin, G.F. (1990). Biometrics. Higher School, Moscow (in Russian). 
Mitrofanov, V.P. (1977). Ekologicheskie osnovy morfologicheskogo analiza ryb (in Russian).

Pivtorak, J.I., \& Bobel, I.Y. (2017). Intensity of growth and development of rainbow trout using feeds Aller Aqua and Aquafeed Fischfutter. Scientific Messenger LNUVMB, 19(79), 73-77. doi: 10.15421/nvlvet7915 (in Ukrainian).

Ruyter, B., Røjø, C., Grisdale-Helland, B. et al. (2010) Influence of temperature and high dietary linoleic acid content on esterification, elongation, and desaturation of PUFA in atlantic salmon hepatocytes. Lipids, 38(8), 833-840. https://www.ncbi.nlm.nih.gov/pubmed/14577662.

Sherman, I.M., Hrynzhevs'kyy, M.V., \& Zheltov, Yu.O. (2002). Naukove obhruntuvannya ratsional'noyi hodivli ryb: uchebnoe posobye, Vyshcha osvita (in Ukrainian).

Thanuthong, T., Francis, D. S., Manickam E. et al. (2011). Fish oil replacement in rainbow trout diets and total dietary PUFA content: II) Effects on fatty acid metabolism and in vivo fatty acid bioconversion. Aquaculture, 322-323, 99-108. doi: 10.1016/j.aquaculture.2011.09.026.

Yun, B., Mai, K., Zhang, W., \& Xu, W. (2011). Effects of dietary cholesterol on growth performance, feed intake and cholesterol metabolism in juvenile turbot (Scophthalmus maximus L.) fed high plant protein diets. Aquaculture, 319(1-2), 105-110. doi: 10.1016/ j.aquaculture.2011.09.028. 